\title{
The Implementation of Anti-Corruption Character Education Through Bali Local Wisdom in Junior High Schools
}

\author{
I Putu Sriartha ${ }^{1^{*}}$, Ni Luh Wayan Yasmiati' ${ }^{2}$ I Wayan Lasmawan ${ }^{3}$ \\ 1,2,3 Postgraduate Program, Universitas Pendidikan Ganesha, Singaraja, Indonesia \\ *e-mail: putusriartha@gmail.com
}

\begin{abstract}
This study aims to evaluate anti-corruption character education through Balinese local wisdom in junior high schools and formulate strategies to strengthen its implementation. The research samples were determined purposively. The evaluation model used was the CIPPO model (Context, Input, Process, Output, Outcome), modified from the CIPP model. Data were collected by interview, observation, and documentation methods. Data analysis was carried out using quantitative descriptive methods and SWOT analysis. The results showed that the implementation of anti-corruption character education was considered effective with an achievement of $76.06 \%$. The highest achievement is on the input variable of $81.75 \%$ (very effective), and the lowest is on the process variable of $61.75 \%$ (less effective). The process of implementing anti-corruption education through learning, habituation, and civilizing is still dominant at the theoretical level, not involving students actively and critically in real life. The SWOT analysis resulted in five strategy formulations, namely: (1) establishment of a character education development unit (anti-corruption), (2) transformation of anti-corruption education learning, (3) exemplary, habituation and civilizing, (4) strengthening extracurricular programs, and (5) building cooperation network.
\end{abstract}

Keywords: Anti-Corruption Education, Balinese Local Wisdom, Junior High School

\section{Introduction}

Corruption is an extraordinary crime, and until now, it has become a crucial problem faced by the Indonesian state and nation. Corruption is still rampant in various regions, at all levels and aspects of life, with various modes (Yanuardi et al., 2021). Transparency International Indonesi reported that in 2020 the Corruption Perception Index (CPI) in Indonesia was recorded at 37 out of a maximum score of 100, ranking 102 out of 180 countries surveyed. In 2019 Indonesia's GPI was better, with a score of 40 of 100, but still relatively low (Sumaryati, 2020; Dewantara et al., 2021) This can be interpreted that corruption cases in Indonesia have not decreased, and there is a tendency to be worse and it brings negative effect toward economic development (Alfada, 2019; Sihombing, 2018). Corrupt behavior in Indonesia has developed systemically, meaning that it has been attached and has become part of society's culture (Mukartono et al., 2019; Talvitie, 2017).

One of the efforts to overcome the rampant culture of corruption is through a preventive approach by effectively implementing anti-corruption education in every education unit (Isra et al., 2017; Petróczi et al., 2021). In addition to the preventive approach, the repressive approach through legal channels is equally important. However, the legal approach that has been implemmented for a long time has not significantly reduced corruption cases (Anand \& Wagh, 2019; Song et al., 2021). The two approaches need to be carried out together to improve thet effectiveness. The Corruption Eradication Commission (CEC) (2017) believe that anti-corruption education plays a strategic role in eradicating corruption. It is because the root of corruption is corrupt cultural behavior that is considered normal and commonly practiced in everyday life (Posthuma, 2021; Pulido et al., 2020). In this context, schools or formal educational institutions have a very important role as the locomotive of anti-corruption education.

\footnotetext{
${ }^{*}$ Corresponding author.

Received July 07, 2021; Accepted September 12, 2021; Available online Desember 25, 2021

This is an open access article under the CC BY-SA license. Copyright (c) 2021 by Author. Published by Universitas Pendidikan Ganesha
} 
The importance of anti-corruption education in schools is not only because schools are centers of civilizing and humanizing humans, but because internally, schools are also one of the institutions prone to corruption (Cai et al., 2021; Mahmoudi \& Majd, 2021; Xu et al., 2021). Corruption is most often found in the education sector, although not all of it is carried out within the scope of schools or campuses (Kul'ba et al., 2021; Mahmoudi \& Majd, 2021). The points that are prone to corruption in schools include procurement of school goods and services, new student admissions, class promotions, and transfer students, acceptance, placement, and transfer of educators and educational staff, administration of tests/exams, supervision, and monitoring of schools. The condition of corruption in education funds was an emergency. In higher education, academic corruption in the form of plagiarism is a common phenomenon that is almost found in all universities in the world (Bowen \& Nanni, 2021; Mahmoudi \& Majd, 2021; Mattar, 2021).

When anti-corruption education assumes that schools are good, the consequence is that teachers and school leaders must first pass anti-corruption education. In other words, they must be clean and free of corruption (Faridli, 2011; Kiromim Baroroh, 2011). Meanwhile, three reasons for the importance of anti-corruption education in schools, namely: (1) schools are centers of developing knowledge and noble culture of the nation, (2) involving educational institutions from elementary to tertiary levels can be transformed into a corruption prevention movement, and (3) the majority of perpetrators of corruption are educated so that educational institutions need to optimize their functions (Kristiono, 2018; Salistina, 2015).

Anti-corruption education is an educational program about corruption that aims to build and increase citizens' awareness of the dangers and consequences of acts of corruption (Anam, 2016; I. Suryani, 2017). Anti-corruption education is part of character education, namely forming human resources with an anti-corruption culture. Furthermore, CEC sets nine character values that lead to anti-corruption behavior: honesty, responsibility, simplicity, caring, independence, discipline, justice, hard work, and courage (Dewantara et al., 2021; Subkhan, 2020). Anti-corruption education in schools can be carried out through several integrated strategies. Three general strategies for anti-corruption education (Darmono, 2017; Dwiputri et al., 2020). First, a school-based management strategy with a focus on professional, transparent, and accountable school management. In this strategy, the actors who play a role are principals, educators, students, and school committees (Kiromim Baroroh, 2011; Salistina, 2015). Second, strategies in learning or curriculum. This strategy includes integration to the appropriate subjects, adopting local wisdom values of the local community that contain anti-corruption values, and self-development (habituation and acculturation, development of extracurricular programs). Third, optimizing community participation. Meanwhile, in the regulations on strengthening character education set by the government, there are intra-curricular, co-curricular, and extracurricular strategies. Relying on existing strategies, the main strategies in implementing anti-corruption education include professional, transparent, and accountable school-based management strategies, learning strategies (intracurricular and co-curricular) through the integration of subjects relevant to local wisdom content, and self-development strategies, which consists of habituation and cultivation as well as extracurricular programs.

Implementing learning strategies in anti-corruption education can be done by integrating them into relevant subjects and utilizing local community social capital or local wisdom that contains anti-corruption values (Dávid-Barrett \& Fazekas, 2020; Xu et al., 2021). One of the subjects relevant to the development of anti-corruption character is the Social Studies subject at the Elementary School and Junior High School levels. This can be understood because social studies deal with people in their interactions with the environment (Alannasir, 2016; Diana Putra et al., 2019; Hutama, 2016). Social Studies Education is a philosophy of educational practice whose focus is on facts, events, phenomena and real problems students face in their lives (Anif et al., 2020; Nugraha et al., 2018). The Social Sciences Laboratory is a human being as a social being. The main purpose of social studies subjects is to form good, democratic, and responsible citizens. In the 2013 Curriculum (C-13) at the junior high school level, the content of social studies subject character education is 
explicitly contained in the Core Competencies (CC), namely: (1) Appreciating and living the religious teachings they adhere to and (2) Appreciating and live honest, disciplined, responsible, caring, polite, confident behavior in interacting effectively with the social and natural environment and its existence.

Local wisdom is quite relevant to be used to increase the effectiveness of anticorruption education learning. This can be understood because local wisdom is a process teaching that is believed to contain truth and goodness. It is lived, taught, practiced, and passed down from generation to generation and become a reference in the daily behaviour of the local society (Marhayani, 2016; Sumardjoko \& Musyiam, 2018; N. A. Suryani \& Haryono, 2018). Local wisdom contains cultural intelligence as a form of student character ((Rochman et al., 2017; Sofyan et al., 2019). Balinese local wisdom has been included in the Bali Governor's Regulation Number 37 of 2019 concerning Anti-Corruption Education (Article 5 ) which stipulates that the implementation of anti-corruption education in formal education units must utilize traditional, cultural, and religious values. Balinese people have a variety of local wisdom. Local Balinese wisdom contains anti-corruption character values, including the belief in the law of karmaphala (karma = action; phala = result). The law of karmaphala teaches that what a person received is the result of what he/she did. Someone who does good things is believed that he/she will get good results, and vice versa. The law of karmaphala contains the character value of honesty. If someone is dishonest, for example, in corruption, then according to the law of karmaphala, the person will sooner or later get a bad reward such as imprisonment. The local Balinese wisdom related to karmaphala is "what is planted, that will be reaped," meaning that one's actions are like planting a plant. Whatever is planted, that's what it will reap. This local wisdom teaches that someone should always have good character and be honest to reap the fruits of goodnes. Balinese local wisdom still has many values that can be used as a source of learning to cultivate characters, especially anticorruption characters, such as Tri Hita Karana, Tri Kaya Parisudha, and others (Ayu et al., 2020; Dwija Putri et al., 2017; Somawati \& Made, 2019; Veronika, 2019).

Comprehensive evaluation research on the implementation of anti-corruption education containing local wisdom in schools is still limited. For example, research the study of enriching anti-corruption values in learning with various methods and media used so that it does not provide a comprehensive picture of how effective the implementation of anticorruption education in schools (Anam, 2016; Faridli, 2011; Salistina, 2015). This study aims to evaluate the effectiveness of the implementation of anti-corruption education through Balinese local wisdom in secondary schools and formulate strategies to increase its effectiveness using the CIPPO evaluation model (Context, Input, Process, Product, and Outcome) as the development of the CIPP model from Stufflebeam (2003).

\section{Method}

This study uses a descriptive type of evaluation research design. This design is used because this study aims to evaluate empirical symptoms that are not artificial in the sample subject. The focus of the evaluation in this study is the implementation of anti-corruption character education containing Balinese local wisdom. The evaluation uses the CIPPO model (Context, Input, Process, Product, and Outcome). The evaluation is carried out comprehensively, covering all forms of implementation of anti-corruption education in schools that are detailed based on context, input, process, product, and outcome. Evaluation in learning is determined purposively for social studies subject considering that this subject has relevance to anti-corruption education.

The research was conducted in Singaraja City with Ganesha Education University Laboratory Junior High School as the representative of private schools and State Junior High School 6 Singaraja as the representtative of state jurnior high schools in Singaraja. The two schools have implemented anti-corruption education through a character education strengthening program based on the initial study. The research subjects were all school leaders, social studies teachers, the head of the school committee, the head of administration, and grade IX students. One class was taken randomly in each school as the 
research sample. Data were collected by interview, documentation, and observation techniques. Specifically, data from students was collected through a questionnaire.

Five types of Balinese local wisdom were the focus of research: (1) Tri Hita Karana, three causes of happiness in life: creating a harmonious relationship with the Creator (God), with fellow humans, and with the natural environment. (2) Tri Kaya Parisudha, three ways to achieve the perfection of life: think, say, and consistently do the right thing. (3) Law of Karmaphala, the belief that the results obtained by humans will be following their actions/karma. (4) the expression "what you sow is what you reap." In other words, what we get is the result of what we have done before. If goodness and truth are planted, the result is goodness and truth. This expression is similar to the law of karmaphala. (5) Tatwam Asi, meaning "you are me, I am you. If you hurt me, then you will feel pain too." It means that we are all brothers. Therefore, we must not hurt each other. Descriptions of variables, indicators, data collection methods, and data sources are presented in Table 1.

Tabel 1. Variable, Indicator, Method, and Source of Data

\begin{tabular}{|c|c|c|c|c|}
\hline No. & Variable & Indicator & Method & Source of Data \\
\hline \multirow[t]{3}{*}{1} & Context & $\begin{array}{l}\text { Vision, mission, objective, } \\
\text { school strategy and } \\
\text { goals }\end{array}$ & $\begin{array}{l}\text { Interviews and } \\
\text { documentation }\end{array}$ & School leaders \\
\hline & & $\begin{array}{l}\text { Character development } \\
\text { policies and proarams }\end{array}$ & $\begin{array}{l}\text { Interviews and } \\
\text { documentation }\end{array}$ & School leaders \\
\hline & & $\begin{array}{l}\text { School Committee } \\
\text { support and role }\end{array}$ & Interviews & $\begin{array}{l}\text { Head of School } \\
\text { Committee }\end{array}$ \\
\hline \multirow[t]{3}{*}{2} & Input & New student recruitment & $\begin{array}{l}\text { Interviews and } \\
\text { documentation }\end{array}$ & School leaders \\
\hline & & School administration & Interviews & Teachers \\
\hline & & Human resources & $\begin{array}{l}\text { Interviews and } \\
\text { documentation }\end{array}$ & $\begin{array}{l}\text { Social Sciences } \\
\text { teachers and the } \\
\text { educational staffs }\end{array}$ \\
\hline \multirow[t]{4}{*}{3} & Process & Habituation and culture & Observation & $\begin{array}{l}\text { Social Sciences } \\
\text { teachers }\end{array}$ \\
\hline & & Instructional instrument & Documentation & $\begin{array}{l}\text { Social Sciences } \\
\text { teachers }\end{array}$ \\
\hline & & $\begin{array}{l}\text { Instructional } \\
\text { implementation }\end{array}$ & Observation & $\begin{array}{l}\text { Social Sciences } \\
\text { teachers }\end{array}$ \\
\hline & & $\begin{array}{l}\text { Assessment of learning } \\
\text { outcomes }\end{array}$ & Documentation & $\begin{array}{l}\text { Social Sciences } \\
\text { teachers }\end{array}$ \\
\hline \multirow[t]{3}{*}{4} & Product & $\begin{array}{l}\text { School leader } \\
\text { characters }\end{array}$ & Interviews & Teachers \\
\hline & & $\begin{array}{l}\text { Characters of teachers } \\
\text { and employees }\end{array}$ & Interviews & Students \\
\hline & & Student characters & $\begin{array}{l}\text { Attitude } \\
\text { questionnaire }\end{array}$ & Students \\
\hline \multirow[t]{2}{*}{5} & Outcome & $\begin{array}{l}\text { School image in the } \\
\text { society }\end{array}$ & Interviews & School Committee \\
\hline & & Alumni Achievements & $\begin{array}{l}\text { Interviews and } \\
\text { documentation }\end{array}$ & $\begin{array}{l}\text { School leaders } \\
\text { and tracer study } \\
\text { documents }\end{array}$ \\
\hline
\end{tabular}

The data analysis technique used was quantitative descriptive analysis and SWOT analysis (Strength, Weakness, Opportunity, and Threats). The first technique was used to analyze the effectiveness of implementing anti-corruption education containing local wisdom, while the second technique to formulate a strategy for implementing anti-corruption education. The indicators of each variable were described in the questions, and each 
question was given a score range of 1 (very bad), 2 (poor), 3 (good), 4 (very good). The ideal score of 1 was converted to a percentage so that it became $25 \%$ and the ideal score of 4 became $100 \%$. Based on the percentage value, the effectiveness assessment criteria were made as in Table 2.

Table 2. Criteria for Assessing the Effectiveness of the Implementation of Anti-Corruption Education through Balinese Local Wisdom

\begin{tabular}{ll}
\hline Interval & Category \\
\hline $25 \%-43 \%$ & Not effective \\
$44 \%-62 \%$ & Lees Effective \\
$63 \%-80 \%$ & Effective \\
$81 \%-100 \%$ & Really effective \\
\hline
\end{tabular}

Furthermore, the research results are calculated to obtain the average score, which is then converted to a percentage using the average score divided by the maximum score (score 4) and multiplied by $100 \%$. The results in the form of percentages are then matched with the criteria in Table 2, so that the level of effectiveness of their implementation can be identified. SWOT analysis was done by identifying the strengths (S), weaknesses (W), opportunities $(\mathrm{O})$, and threats $(\mathrm{T})$. Furthermore, a qualitative analysis of $\mathrm{S}-\mathrm{O}$ (using strengths by taking advantage of opportunities), S-T (using strengths by avoiding threats), W-O (overcoming weaknesses by taking advantage of opportunities), and W-T (minimizing weaknesses by avoiding threats). Based on this analysis, several strategies were formulated to strengthen the implementation of anti-corruption character education through Balinese local wisdom.

\section{Result and Discussion}

\section{Results}

The evaluation results of the anti-corruption character education through Balinese local wisdom using the CIPPO model are presented in Table 3.

Table 3. Evaluation Results of Anti-Corruption Education Implementation through Balinese Local Wisdom

\begin{tabular}{|c|c|c|c|c|}
\hline No. & Variable & Indicator & $\begin{array}{l}\text { Mean } \\
\text { Score }\end{array}$ & Category \\
\hline \multirow[t]{4}{*}{1} & Context & $\begin{array}{l}\text { Vision, Mission, Objective. } \\
\text { school strategy and goals }\end{array}$ & 78.25 & Effective \\
\hline & & $\begin{array}{l}\text { Character development policies } \\
\text { and programs }\end{array}$ & 83.75 & Really effective \\
\hline & & $\begin{array}{l}\text { School Committee support and } \\
\text { role }\end{array}$ & 68.0 & Effective \\
\hline & & Mean Score & 76.50 & Effective \\
\hline \multirow[t]{4}{*}{2} & Input & New student recruitment & 86.0 & Really effective \\
\hline & & School administration & 90.75 & Really effective \\
\hline & & Human resources & 68.50 & Effective \\
\hline & & Mean Score & 81.75 & Really effective \\
\hline \multirow[t]{5}{*}{3} & Process & Habituation and culture & 54.25 & Less effective \\
\hline & & Instructional instrument & 66.75 & Effective \\
\hline & & Instructional implementation & 70.0 & Effective \\
\hline & & Assessment of learning outcomes & 56.25 & Less effective \\
\hline & & Mean Score & 61.81 & Less effective \\
\hline \multirow[t]{2}{*}{4} & Product & School leader characters & 83.13 & Really effective \\
\hline & & $\begin{array}{l}\text { Characters of teachers and } \\
\text { employees }\end{array}$ & 83.13 & Really effective \\
\hline
\end{tabular}




\begin{tabular}{lllll}
\hline \multirow{2}{*}{ No. } & \multirow{2}{*}{ Variable } & \multicolumn{1}{c}{ Indicator } & \multicolumn{1}{c}{$\begin{array}{c}\text { Mean } \\
\text { Score }\end{array}$} & \multicolumn{1}{c}{ Category } \\
\hline \multirow{4}{*}{5} & \multirow{3}{*}{ Outcome } & 75.0 & Effective \\
& & Student characters & 80.50 & Effective \\
& & Mean Score & 84.50 & Really effective \\
& & School image in the society & 75.0 & Effective \\
& & Alumni Achievements & 79.75 & Effective \\
\hline
\end{tabular}

Based on the description of the research results in Table 3, it is found that the implementation of the input variables was very effective, with an achievement of $81.75 \%$. Three variables, namely: context, product, and outcome of the implementation were considered effective with percentage values of $76.50 \%, 80.50 \%$, and $79.75 \%$, respectively. In contrast, the variable with the lowest percentage value was the process variable of $61.81 \%$ and was classified as less effective. Overall, implementing anti-corruption character education containing Balinese local wisdom reached $76.06 \%$ and was included in the effective category. The results of this study can be described in a pentagonal model of the implementation of anti-corruption character education through local wisdom, as shown in Figure 1.

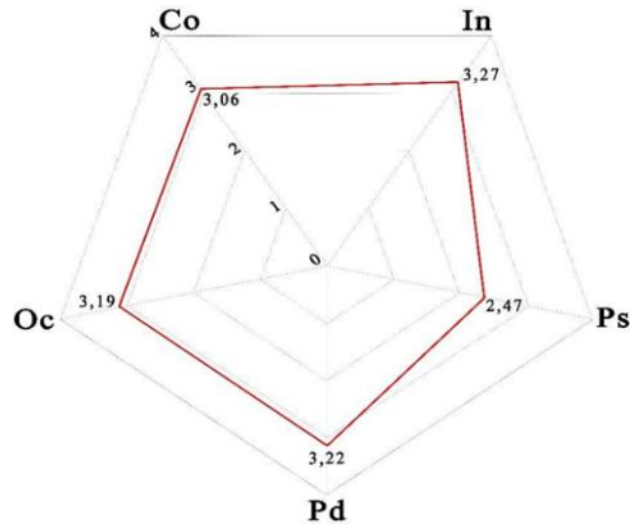

Figure 1. Pentagonal Model of Anti-Corruption Education Implementation Note: $\mathrm{Co}=$ Contex; In = Input; Ps = Process; Pd = Product; Oc = Outcome.

Research evaluating character education programs in elementary schools using qualitative methods (data reduction - data presentation - data verification). It was revealed that the implementation of character education was only limited to being integrated into the curriculum with some obstacles faced, namely: (1) the knowledge, understanding, and skills of teachers in implementing character education were still low, (2) its implementation in learning had not been seen, (3) school synergy with education at home was not optimal, and (4) there was no documented output in the form of student attitudes about character education. Darmayanti and Wibowo's research is different from this study. Their research did not use the CIPPO model, the method is qualitative, and they did not measure students' attitudes towards character education. However, the research has similar results with this study, especially in the constraints faced by schools, namely: teachers' low knowledge, skills, and understanding, low implementation in the learning process, and school synergy with parents represented through the School Committee had not run optimally.

The nine important anti-corruption characters built through character education programs in schools: honest, disciplined, responsible, fair, brave, caring, hard-working, independent, and simple. This study found that most of the anti-corruption character values set by the CEC have been stated in the vision, mission, goals, and policies of school programs that are integrated into the Character Education Program (CEP). Only three anticorruption character values are yet to be seen: hard work, courage, and simplicity. The implementation process (process variables) showed less effective results, especially still 
weak in its implementation in the learning process and assessment applied by social studies teachers. Judging from the product variables, social studies leaders and teachers have played the characters of honesty, discipline, responsibility, and openness with very effective categories. Meanwhile, the students' attitudes towards the four anti-corruption characters (honest, responsibility, discipline, and hard work) were considered effective.

Concerning the use of Balinese local wisdom in anti-corruption character education programs, the two schools where the research has been carried out have included some local Balinese wisdom in the school's vision, mission, goals, and programs. Both schools include the philosophy of Tri Hita Karana (THK) in the formulation of the school's vision. The Undiksha Laboratory Junior High School program includes the local wisdom of Tri Kaya Parisudha, Paras Paros Sarpanaya sagilik saguluk Selunglung Sebayantaka, Tatwam Asi, and Menyamabraya, while the State Junior High School 6 Singaraja Tri Kaya Parisudha. The values of Balinese local wisdom that contain anti-corruption character values that have not been utilized in research schools are the Law of Karmaphala, Tatwam Asi, and Catur Purusa Artha. Based on the results of this study, it can be interpreted that there are variations in the content of Balinese local wisdom values between schools, not all local wisdom values with anti-corruption characteristics have been adopted by schools. In practice, the implementation is not yet clear and not optimal. One of the causes is the lack of knowledge and understanding of school managers and teachers about the values of Balinese local wisdom and the absence of clear institutions and governance in the implementation of character education programs, especially anti-corruption character education containing Balinese local wisdom.

The use of the THK philosophy in the formulation of the vision in the two schools studied was considered appropriate in the context of the character education strengthening program, especially the anti-corruption character because THK as a Balinese philosophy has been rooted in the lives of Balinese people and it contains various character values. THK is a Balinese philosophy that comes from Hinduism and has become part of daily life practice both in the family environment, traditional villages, offices, tourism, agriculture, and other aspects of life (Sriartha \& Giyarsih, 2015). However, in implementing the THK, it is necessary to deepen the understanding of the THK because THK can be misused in a negative direction. That is why school managers and teachers, the locomotive of the character education program, need to first deepen their knowledge and understanding of Balinese local wisdom such as THK before practicing it in school life. This is in line with what stated that a person's low knowledge and understanding of THK could lead to misuse of the normative ideal values of THK towards unwiseness in the form of collusion, corruption, and nepotism $(\mathrm{CCN})$. This is based on the understanding that THK values can have both positive and negative implications. One of the reasons for CCN is that the normative ideal value of the pawongan component in THK is used as an excuse to fulfill one's ego of power, leading to CCN behavior.

The values of Balinese local wisdom are full of anti-corruption values, but they have not been used as the core material in anti-corruption character education programs in schools. The values of local wisdom are the law of karmaphala, the expression "what is planted is what will be reaped," and Catur Purusa Artha. The law of karmaphala deals with honesty. If people are dishonest, then according to the law of karmaphala, sooner or later they will get negative results - negative phala such as prison and/or hell. The law of karmaphala can be integrated with the expression "what is planted is what will be reaped," which means One's actions are like planting a plant. This local wisdom teaches that one should always do good things (honest) - not being corrupt to reap the fruits of goodness and safety. While the teachings of catur purusa artha remind one to always live in balance and simplicity by prioritizing dharma (truth) first, then artha (matter), kama (controlled lust), and moksha (as the ultimate goal of life). But ironically, in today's capitalist era, many people prioritize artha and kama over dharma, so this phenomenon can encourage corruption cases to rise. 


\section{Discussion}

In this study, SWOT analysis with a qualitative approach was used to formulate strategies for strengthening character education in schools. The analysis started by identifying the strengths, weaknesses, opportunities, and threats of the school. After that, analysis and strategy formulation was carried out, and the results are listed in Table 4.

Table 4. Matrix of SWOT Analysis Results for Strengthening Anti-Corruption Education Strategies in Schools

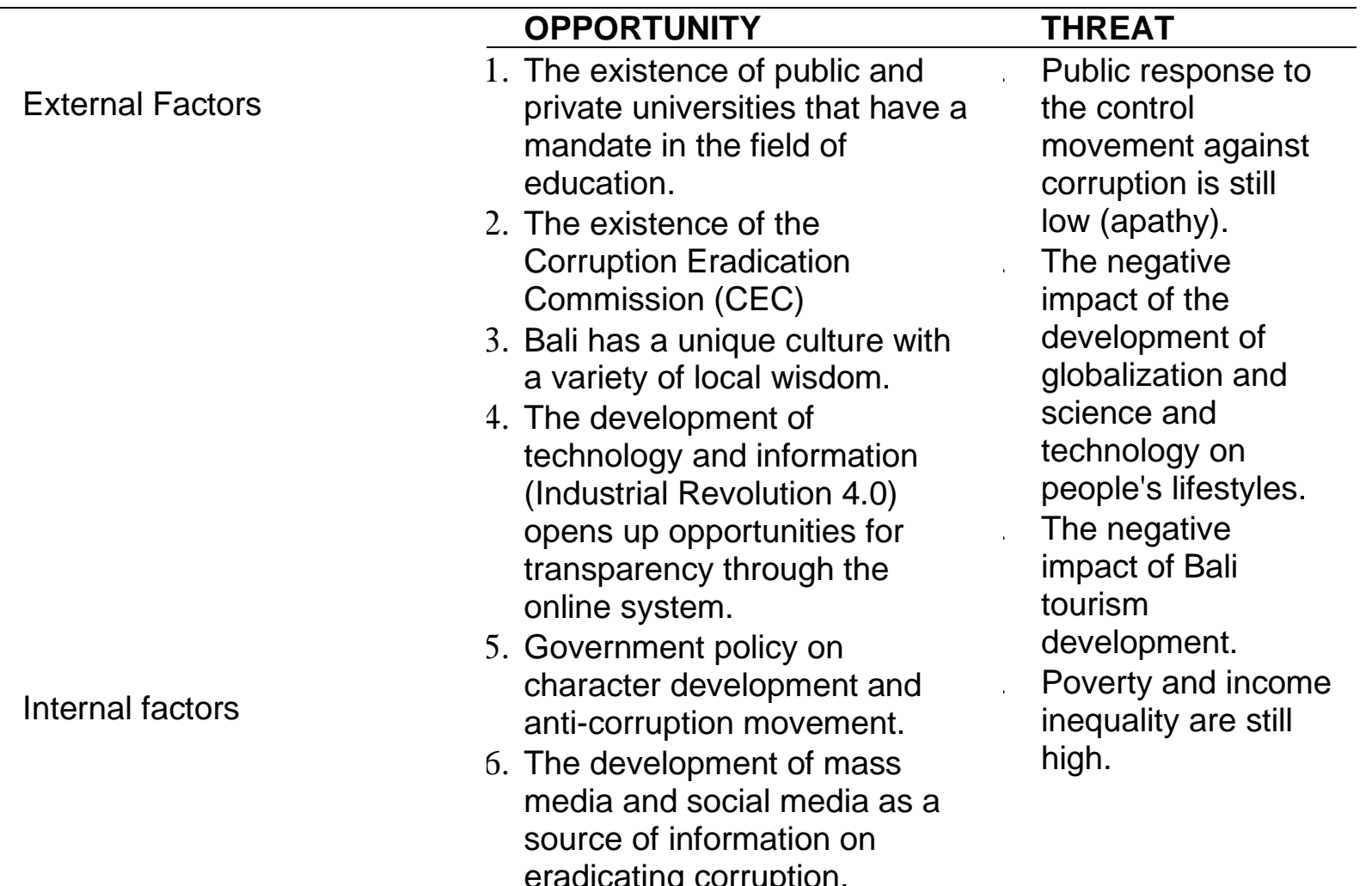

\section{STRENGTH}

1. Adequate number of school human resources.

2. The school's vision and mission cover the development of character education and Balinese local wisdom.

3. The academic qualifications of teachers and staff are good.

4. Adequate educational infrastructure and facilities.

5. Commitment of leaders and teachers in developing anti-corruption character.

6. There is a forum for extracurricular development under the coordination of the eradicating corruption.

STRATEGY S-O

\section{TRATEGY S-T}

1. Developing cooperation networks with external parties (universities, other schools, government, anti-corruption institutions, and other relevant agencies).

2. Strengthening the curriculum includes anti-corruption character education in every subject with outdoor study to institutions related to eradicating corruption.

3. Developing information technology 4.0 in school management (learning, human resources, and digital-based financial administration).
Developing cultural or school habituation with national character and based on local cultural values.

Developing school entrepreneurship programs for scholarships and other social assistance for economically disadvantaged students.

Developing and strengthening students' organization with extracurricular activity units based 
Student Council.

on anti-corruption character education and Balinese local wisdom.

WEAKNESS
1. Weak understanding of
school residents towards
Balinese local wisdom and
anti-corruption character
development.

2. It is difficult to manage time with limited availability.

3. The system for implementing, supervising, monitoring, and evaluating character development programs is limited.

4. The School Committee has not played an optimal role in character development.

5. There is no special unit that handles character education (anti-corruption).

Based on the detailed results of the S-O, ST, W-O, and W-T strategies as shown in Table 4, five main strategies within schools can be recommended to develop anti-corruption character education through Balinese local wisdom, namely: First, Developing units/fields/task units such as the Center for Character Education Development. This unit has the main task and function of planning, implementing, monitoring, and evaluating character education development programs (including anti-corruption) containing Balinese local wisdom. These programs include preparing teaching materials and standard operating procedures (SOP) related to anti-corruption education containing Balinese local wisdom, training/workshops/seminars on character strengthening, competitive programs (contests) on anti-corruption character education through local wisdom. Second, Learning. This strategy specifically develops anti-corruption character education containing Balinese local wisdom through intra-curricular activities. The learning strategy must be transformed from learning that is packed with theoretical material on anti-corruption values and teachings of morality to involve students actively and critically in examining issues and information on corrupt practices in real life (Dewantara et al., 2021; Jandhyala \& Oliveira, 2020; Park \& Xiao, 2021).

This anti-corruption education is currently still at the theoretical level and has not touched the real action of how students can act and behave firmly against corrupt practices. Three important principles to go in that direction are democratic, contextual learning that leads to real attitudes and actions (Johansen et al., 2020; Kim, 2021; Subkhan, 2020). The target of chacacter education (anticorruption) is moral feeling and moral action, not moral knowing. The implementation of this strategy is under the management of the curriculum field and in coordination with the center/unit of character education development (anti-corruption) (Kadir, 2018; Kiromim Baroroh, 2011). Third, Developing school habituation and culture. This strategy includes socialization activities and internalization of anti-corruption culture, which are carried out routinely in schools. The programs include ceremonies in commemorating anti-corruption day and other national holidays, installing anti-corruption billboards and pictures containing anti-corruption moral messages in strategic places in the school environment, and applying anti-corruption behavior role models from leaders, teachers, and employees in governance and management (Dwiputri et al., 2020; Kristiono, 2018). Manage schools and daily behavior and other habits such as saying "anti-corruption greetings" at important meetings, posting activity and financial reports on school bulletin boards, and other 
habits.

Fourth, Developing Extracurricular Activities. This strategy is implemented in intraschool student organizations, student activities such as scouts, youth red cross, student arts groups, student sports groups, and others under the student field and coordination with character development centers/units (Juwantara, 2019; Pratiwi, 2020). Fifth, Building cooperation and networking. This potential is strategically developed under the command of the principal. Various opportunities that exist in the external environment can be utilized to build anti-corruption attitudes and behavior. The forms of cooperation, for example, are inviting resource persons from the CEC, from universities, local governments, bringing in success stories of former corruptors who have become aware of and become anti-corruption volunteers, and other forms. The five strategies are a single unit so that in their implementation requires the principles itegration and holistic. The evaluation of CIPPO model and five main strategies for developving anti-corruption education produced in this study can be applied in the other schools by taking into account the conditions of each school.

\section{Conclusions and Suggestions}

This study reveals that implementing anti-corruption education in junior high schools seen from the process variable is classified as less effective. Anti-corruption education applied through learning, habituation, and civilizing is still dominant in providing theoretical knowledge about anti-corruption values, not yet optimally involving students' real actions in collecting, analyzing, and reflecting on various information and facts corruption in real life around their environment. Meanwhile, judging from the other variables (context, input, output, and outcome), it is classified as effective with varying percentages. This has implications for the importance of transforming the implementation process of anti-corruption education centered on students' real actions in addressing corruption issues in real life in their environment.

\section{References}

Alannasir, W. (2016). Pengaruh Penggunaan Media Animasi Dalam Pembelajaran IPS Terhadap Motivasi Belajar Siswa Kelas IV SD Negeri Mannuruki. Journal of Educational Science and Technology, 2(2), 81-90. https://doi.org/10.26858/est.v2i2.2561.

Alfada, A. (2019). The destructive effect of corruption on economic growth in Indonesia: A threshold model. Heliyon, https://doi.org/10.1016/j.heliyon.2019.e02649.

Anam, M. A. S. (2016). Lembaga Pendidikan Islam Sebagai Wahana Implementasi Pendidikan Anti Korupsi. Jurnal Pendidikan Agama Islam (Journal of Islamic Education Studies), 3(2). https://doi.org/10.15642/jpai.2015.3.2.368-392.

Anand, D., \& Wagh, R. (2019). Effective deep learning approaches for summarization of legal texts. Journal of King Saud University - Computer and Information Sciences. https://doi.org/10.1016/j.jksuci.2019.11.015.

Anif, S., Sutopo, A., \& Prayitno, H. J. (2020). Lesson study validation: Model for social and natural sciences teacher development in the implementation of national curriculum in Muhammadiyah schools, Indonesia. Universal Journal of Educational Research, 8(1), 253-259. https://doi.org/10.13189/ujer.2020.080132.

Ayu, D., Manu, M., \& Priantini, O. (2020). The Development Of Teaching Video Media Based On Tri Kaya Parisudha In Educational Psychology Courses. Journal of Education Technology, 4, 448-455.

Bowen, N. E. J. A., \& Nanni, A. (2021). Piracy, playing the system, or poor policies? Perspectives on plagiarism in Thailand. Journal of English for Academic Purposes, 51. https://doi.org/10.1016/j.jeap.2021.100992.

Cai, W., Hu, F., Xu, F., \& Zheng, L. (2021). Anti-corruption campaign and corporate cash holdings: Evidence from China. Emerging Markets Review. 
https://doi.org/10.1016/j.ememar.2021.100843.

Darmono, A. (2017). Pendidikan Anti Korupsi Berpendekatan Klarifikasi Nilai Di Sekolah Dasar. An Nuha: Jurnal Kajian Islam, Pendidikan, Budaya \& Sosial, 4(1).

Dávid-Barrett, E., \& Fazekas, M. (2020). Anti-corruption in aid-funded procurement: Is corruption reduced or merely displaced? World Development Perspectives, 132. https://doi.org/10.1016/j.worlddev.2020.105000.

Dewantara, J. A., Hermawan, Y., Yunus, D., Prasetiyo, W. H., Efriani, E., Arifiyanti, F., \& Nurgiansah, T. H. (2021). Anti-corruption education as an effort to form students with character humanist and law-compliant. Media Kajian Kewarganegaraan, 18(1), 7081. https://doi.org/10.21831/jc.v18i1.38432.

Diana Putra, I. D. G., Darsana, I. W., \& Putra, M. (2019). Pengaruh Model Pembelajaran Berbasis Masalah Berbantuan Peta Konsep Terhadap Kompetensi Pengetahuan IPS. Jurnal IImiah Sekolah Dasar, 3(3), 387. https://doi.org/10.23887/jisd.v3i3.19479.

Dwija Putri, I. G. A. M. A., Ulupui, I. G. K. ., \& Wirawati, N. G. P. (2017). Pengaruh Good Corporate Governance dan Budaya Tri Hita Karana Pada Kinerja Bank Perkreditan Rakyat. Jurnal IImiah Akuntansi Dan Bisnis, 17. https://doi.org/10.24843/jiab.2017.v12.i01.p03.

Dwiputri, I. N., Putri, R. D., Mintarti, S. U., Rachmawati, D., \& Megasari, R. (2020). Program Pendidikan Anti Korupsi pada Siswa Sekolah Menengah Atas (SMA). Ethos: Jurnal Penelitian Dan Pengabdian Kepada Masyarakat, 8(2). https://doi.org/10.29313/ethos.v8i2.5407.

Faridli, E. M. (2011). Pengaruh Model Project Citizen Dalam Pembelajaran Pendidikan Kewarganegaraan Terhadap Penanaman Nilai-Nilai Anti Korupsi Siswa Sma Pada Konsep Sistem Hukum Dan Peradilan Nasional. Khazanah Pendidikan, 3(2). https://doi.org/10.30595/jkp.v3i2.645.

Hutama, F. S. (2016). Pengembangan Bahan Ajar IPS Berbasis Nilai Budaya Using Untuk Siswa Sekolah Dasar. JPI (Jurnal Pendidikan Indonesia), 5(2), 113. https://doi.org/10.23887/jpi-undiksha.v5i2.8359.

Isra, S., Yuliandri, Amsari, F., \& Tegnan, H. (2017). Obstruction of justice in the effort to eradicate corruption in Indonesia. International Journal of Law, Crime and Justice, 51. https://doi.org/10.1016/j.ijlcj.2017.07.001.

Jandhyala, S., \& Oliveira, F. S. (2020). The role of international anti-corruption regulations in promoting socially responsible practices. Journal of Economic Behavior \& Organization, 190. https://doi.org/10.1016/j.jebo.2021.07.017.

Johansen, C., Chisholm, B., Secong, D., Sihat, A., \& Candidate, S. M. P. (2020). Building Competency-Based Practice Into Democratically Elected Boards. Journal of Nursing Regulation, 10(4). https://doi.org/10.1016/S2155-8256(20)30008-9.

Juwantara, R. A. (2019). Analisis Teori Perkembangan Kognitif Piaget Pada Tahap Anak Usia Operasional Konkret 7-12 Tahun dalam Pembelajaran Matematika. Jurnal IImiah Pendidikan Guru Madrasah Ibtidaiyah, 9(1), 27-34. https://doi.org/10.18592/aladzkapgmi.v9i1.3011.

Kadir, Y. (2018). Anti Corruption Attitude Of Students As A Corruption Meusure of Criminal Meusures. Subtantive Justice, International Journal of Law, 1(2), 114-128. https://doi.org/10.33096/substantivejustice.v1i2.19.

Kim, T. (2021). The impact of election outcome on internal political efficacy: The role of $\begin{array}{llll}\text { contextual } \quad \text { factors. } & \text { Stectoral }\end{array}$ https://doi.org/10.1016/j.electstud.2021.102406.

Kiromim Baroroh. (2011). Integrasi Nilai-Nilai Anti Korupsi Dalam Pembelajaran Ekonomi di Sekolah Menengah Atas. Informasi, https://doi.org/10.21831/informasi.v1i1.4460.

Kristiono, N. (2018). Penanaman Nilai Antikoroupsi Bagi Mahasiswa Fis Unnes Melalui Mata Kuliah Pendidikan Anti Korupsi. Refleksi Edukatika. https://doi.org/10.24176/re.v9i1.2807.

Kul'ba, V. V., Shelkov, A. B., \& Avdeeva, Z. K. (2021). Analysis of Anti-corruption Management Effectiveness Based on the Scenario Approach (on the Example of the 
Construction

Industry).

IFAC-PapersOnLine,

54(3).

https://doi.org/10.1016/j.ifacol.2021.10.436.

Mahmoudi, F., \& Majd, R. B. (2021). The effect of lean culture on the reduction of academic corruption by the mediating role of positive organizational politics in higher education. International Journal of Educational Development, 80. https://doi.org/10.1016/j.ijedudev.2020.102319.

Marhayani, D. A. (2016). Development of Character Education Based on Local Wisdom in Indegenous People Tengahan Sedangagung. JETL (Journal Of Education, Teaching and Learning), 1(2), 66. https://doi.org/10.26737/jetl.v1i2.40.

Mattar, M. Y. (2021). Combating Academic Corruption and Enhancing Academic Integrity through International Accreditation Standards: The Model of Qatar University. Journal of Academic Ethics, 0123456789. https://doi.org/10.1007/s10805-021-09392-7.

Mukartono, A., Hartiwiningsih, \& Rustamaji, M. (2019). The Development of Corruption in Indonesia (is Corruption a Culture of Indonesia?) BT - Proceedings of the 3rd International Conference on Globalization of Law and Local Wisdom (ICGLOW 2019). 139-141. https://doi.org/10.2991/icglow-19.2019.36.

Nugraha, Y. A., Handoyo, E., \& Sulistyorini, S. (2018). Traditional Game on The Social Skill of Students in The Social Science Learning of Elementary School. Journal of Primary Education, 7(2), 220-227. https://doi.org/10.15294/jpe.v7i2.23475.

Park, B. II, \& Xiao, S. (Simon). (2021). Doing good by combating bad in the digital world: Institutional pressures, anti-corruption practices, and competitive implications of MNE foreign subsidiaries. Journal of Business Research, 137. https://doi.org/10.1016/j.jbusres.2021.08.014.

Petróczi, A., Heyes, A., Thrower, S. N., Martinelli, L. A., Backhouse, S. H., \& Boardley, I. D. (2021). Understanding and building clean(er) sport together: Community-based participatory research with elite athletes and anti-doping organisations from five European countries. Psychology of Sport and Exercise, 55. https://doi.org/10.1016/j.psychsport.2021.101932.

Posthuma, R. A. (2021). High Compliance Work Systems: Innovative Solutions for Firm Success and Control of Foreign Corruption. Business Horizons. https://doi.org/10.1016/j.bushor.2021.02.038.

Pratiwi, S. I. (2020). Pengaruh Ekstrakurikuler Pramuka Terhadap Karakter Disiplin Siswa SD. Edukatif: Jurnal IImu Pendidikan, 2(1), 62-70. https://doi.org/10.31004/edukatif.v2i1.90.

Pulido, N. R., Poveda, A. C., \& Carvajal, J. E. M. (2020). Corruption and instutitions: An analysis for the Colombian case. Heliyon, 6(9), e04874. https://doi.org/10.1016/j.heliyon.2020.e04874.

Rochman, C., Nasrudi1, D., Rokayah, R., Hermita, N., Malik, A., \& Suhada, I. (2017). Integration of Local Wisdom in Science Learning. Proceedings of the 2nd Asian Education Symposium (AES, 424-428. https://doi.org/10.5220/0007305504240428.

Salistina, D. (2015). Pendidikan Anti Korupsi melalui Hidden Curriculum dan Pendidikan Moral. Ta'allum: Jurnal Pendidikan Islam, 3(2). https://doi.org/10.21274/taalum.2015.3.2.163-184.

Sihombing, S. O. (2018). Youth perceptions toward corruption and integrity: Indonesian context. Kasetsart Journal of Social Sciences, 39(2), 299-304. https://doi.org/10.1016/j.kjss.2018.03.004.

Sofyan, H., Anggereini, E., \& Saadiah, J. (2019). Development of E-Modules Based on Local Wisdom in Central Learning Model at Kindergartens in Jambi City. European Journal of Educational Research, 8(4), 1137-1143. https://doi.org/10.12973/eu-jer.8.4.1137.

Somawati, A. V., \& Made, Y. A. D. N. (2019). Implementasi Ajaran Tri Kaya Parisudha Dalam Membangun Karakter Generasi Muda Hindu Di Era Digital. Jurnal Pasupati, 6(1). https://doi.org/10.37428/pspt.v6i1.135.

Song, D., Vold, A., Madan, K., \& Schilder, F. (2021). Multi-label legal document classification: A deep learning-based approach with label-attention and domain-specific pre-training. Information Systems Journal. https://doi.org/10.1016/j.is.2021.101718. 
Sriartha, I. P., \& Giyarsih, S. R. (2015). Spatial Zonation Model of Lokal irrigation System Sustainability (A Case of Subak System in Bali. Indonesian Journal of Geography, 47, 2. https://doi.org/10.22146/ijg.9253.

Subkhan, E. (2020). Pendidikan Antikorupsi Perspektif Pedagogi Kritis. INTEGRITAS: Jurnal Antikorupsi, 6(1), 15-30. https://doi.org/10.21154/asanka.v2i2.2990.

Sumardjoko, B., \& Musyiam, M. (2018). Model of civic education learning based on the local wisdom for revitalizing values of pancasila (Bahasa Indonesia). Cakrawala Pendidikan, 37(2), 201-211. https://doi.org/10.21831/cp.v37i2.18037.

Sumaryati. (2020). Penguatan pendidikan antikorupsi perspektif essensialisme. Jurnal Antikorupsi. INTEGRITAS, 6(1), 01-14. https://doi.org/10.32697/integritas.v6i1.40.

Suryani, I. (2017). Penanaman Nilai Anti Korupsi Di Perguruan Tinggi Sebagai Upaya Preventif Pencegahan Korupsi. Jurnal Visi Komunikasi, 12(2). https://doi.org/10.22441/jvk.v12i2.413.

Suryani, N. A., \& Haryono, M. (2018). Improvement of the Logical Intelligence Through Media Kolak (Collage Numbers) Based on Local Wisdom on Early Childhood. Jurnal Obsesi: Jurnal Pendidikan Anak Usia Dini, 2(2), 253. https://doi.org/10.31004/obsesi.v2i2.90.

Talvitie, A. (2017). Observed Differences in Corruption between Asia and Africa: The Industrial Organization of Corruption and Its Cure. Transportation Research Procedia, 25, 4472-4490. https://doi.org/10.1016/j.trpro.2017.05.357.

Veronika, A. (2019). Implementasi Ajaran Tri Kaya Parisudha Dalam Membangun Karakter Generasi Muda Hindu Di Era Digital. Jurnal PASUPATI. https://doi.org/10.37428/pspt.v6i1.135.

Xu, G., Wang, X., Wang, R., Yano, G., \& Zou, R. (2021). Anti-corruption, safety compliance and coal mine deaths: Evidence from China. Journal of Economic Behavior \& Organization, 188. https://doi.org/10.1016/j.jebo.2021.05.013.

Yanuardi, Y., Vijge, M. J., \& Biermann, F. (2021). Improving governance quality through global standard setting? Experiences from the Extractive Industries Transparency Initiative in Indonesia. The Extractive Industries and Society, 100905. https://doi.org/10.1016/j.exis.2021.100905. 